\title{
Obesity in Pregnancy - Implications on Pregnancy Events
}

\author{
Lilia Koleva ${ }^{1}$, Victoria Spasova ${ }^{2 *}$, Marieta Popova ${ }^{3}$, Valentina Petkova ${ }^{4}$, Milen Dimitrov ${ }^{5}$ \\ ${ }^{1}$ Clinic of Operative Surgery, UMBALSM "Pirogov", Sofia, Bulgaria; 'Department of Medical Genetics, Faculty of Medicine, \\ Medical University of Sofia, Sofia, Bulgaria; ${ }^{3}$ Second Gynecology clinic, University Hospital of Obstetrics and Gynecology \\ "Maichin Dom", Sofia, Bulgaria; ${ }^{4}$ Department of Obstetrics and Gynecology, Medical University of Sofia, Sofia, Bulgaria; \\ ${ }^{5}$ Faculty of Pharmacy, Medical University, Sofia, Bulgaria
}

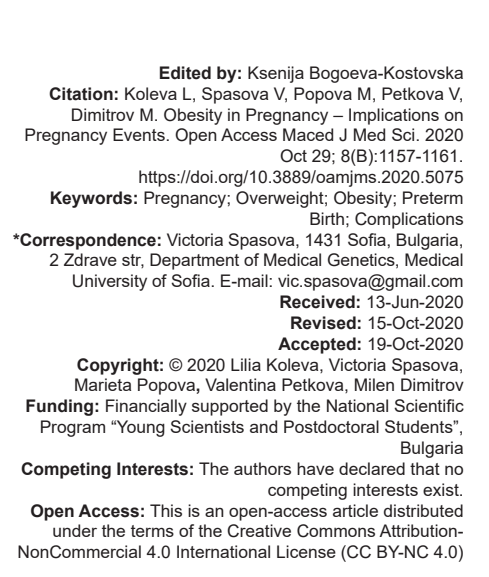

Abstract

BACKGROUND: Overweight and obesity are serious health problems in most developed countries. The percentage of young women with excessive weight who get pregnant continues to grow every year. This raises a concern about the risks of the mother and the baby during pregnancy and after birth.

AIM: This study aims to determine health risk for overweight mothers and especially the risk for preterm birth.

MATERIALS AND METHODS: This is a prospective and retrospective study taking place in the outpatient clinic of the University Hospital "Maichin Dom". Our study included 105 pregnant women with BMI $\geq 25 \mathrm{~kg} / \mathrm{m}^{2}$ as a case group and 91 pregnant women with BMI within normal limits as a control group.

RESULTS: Mean BMI in the case group was $34.79 \pm 3.71 \mathrm{~kg} / \mathrm{m}^{2}$ and $20.20 \pm 2.24 \mathrm{~kg} / \mathrm{m}^{2}$ in the control group. Among 105 women in the case group, we registered $24.8 \%(n=26)$ who gave birth before term. Preterm births among 91 women in the control group were registered in $17.6 \%(n=16)$ patients. We found a significant correlation between increased $\mathrm{BMI}$ and the risk of increased systolic and diastolic blood pressure. Moreover, we found comorbidities in $43.8 \%$ of cases and $24.2 \%$ of controls.

CONCLUSION: Maternal overweight and obesity during pregnancy are associated with increased risks of preterm delivery and complications of pregnancy. Extra efforts should be made to help women lose weight before this important period of life.

\section{Introduction}

World Health Organization reports that $39 \%$ of adults aged 18 years and over were overweight in 2016 , and $13 \%$ were obese. The prevalence of excess body weight in Bulgaria is similar. According to the National Statistical Institute of the Republic of Bulgaria, $40 \%$ of citizens above 15 years of age are overweight or obese. The statistics also show that $43 \%$ of Bulgarian women have $\mathrm{BMI} \geq 25 \mathrm{~kg} / \mathrm{m}^{2}$.

Pregnancy-associated weight gain which is outside the recommended ranges is a serious risk factor for various adverse maternal outcomes, including pregnancy-associated hypertension, hyperglycemic disturbances, and $\mathrm{HbA} 1 \mathrm{c} \geq 6.5 \%$ [1]. Other adverse effects of weight gain reported in the literature are anemia, bleeding, insulin resistance, intrauterine growth restriction (IUGR), and increased risk for preterm birth [2], [3]. Women with obesity are at risk for preterm birth but the exact relationship between different classes is still not clear [4]. A study among Swedish future mothers concluded that maternal overweight and obesity during pregnancy were associated with increased risks of preterm delivery, especially extremely preterm delivery [5].
Overweight may impact pregnancy in many different mechanisms some of which include abnormal growth of the fetus and the placenta, alteration in the transport of nutrients reaching the fetus, as well as changes in the normal metabolism. Weight gain is a key factor for the pregnancy outcome [3].

Different studies conclude that obesity and overweight have higher frequency among shorter, older, multiparous, lower-educated women, and in women with chronic diseases such as hypertension and diabetes [6], [7].

As the overweight prevalence is increasing in the last decades among young women in Bulgaria, we see it as a serious problem. We have conducted this survey I to gather more information about the outcomes of women's weight gain over their pregnancies.

\section{Materials and Methods}

\section{Study design}

This is a retrospective and prospective casecontrol study that is conducted using data from women 
whose pregnancy was monitored in the outpatient clinic of the University Hospital of Obstetrics and Gynecology "Maichin Dom", Sofia, Bulgaria.

\section{Cases}

Study cases are 105 pregnant patients of the clinic with overweight or obesity. Overweight is defined as BMI between 25 and $29.9 \mathrm{~kg} / \mathrm{m}^{2}$. Obesity is defined as $\mathrm{BMI} \geq 30 \mathrm{~kg} / \mathrm{m}^{2}$.

\section{Controls}

Study controls are 91 pregnant patients of the Clinic with $\mathrm{BMI} \leq 24.9 \mathrm{~kg} / \mathrm{m}^{2}$.

\section{Data collection}

Information was collected on women's age, height, weight, parity, and miscarriages at their first visit to the clinic. Weight and height were obtained under standardized conditions during the 12-14 week of pregnancy and were used to calculate BMI.

Women's blood pressure was obtained using an upper arm automatic blood pressure monitor at each visit after the 20 g.w. Following the recommendations of the European Cardiology Society, we considered gestational hypertension when women's blood pressure was systolic $\geq 140 \mathrm{~mm} \mathrm{Hg}$ diastolic $\geq 90 \mathrm{~mm}$ $\mathrm{Hg}$ in two separate occasions at least 4 days apart with the exclusion of proteinuria. Patient's response to glucose was obtained using oral glucose challenge test (OGCT) with $50 \mathrm{~g}$ of glucose between weeks 24 and 28 of pregnancy.

Thyroiditis, chronic gastritis, and varicose veins were diagnosed before pregnancy, respectively, by an endocrinologist, a gastroenterologist, and a vascular surgeon. Thyroid function was monitored by measuring TSH, anti-TPO, and TgAb every four weeks. Dosage adjustments of levothyroxine were done when needed. Women having gastritis had the disease under control and none of them needed any specific procedures or treatment during pregnancy. Women having varicose veins were advised for lifestyle changes.

Other variables we have studied were a gestational week at birth, Apgar score at $1^{\text {st }}$ and $5^{\text {th }}$ min, and newborn's weight. Each birth before 37 weeks of gestation was classified as preterm. A birth between 37 and 41 weeks of gestation was classified as on-term birth, and after 41 gestational weeks - as a post-term birth.

\section{Statistical analysis}

Quantitative variables are presented as mean values (arithmetic mean and median), standard deviations, minimum and maximum values. Variable categories are presented by $(n)$ and relative (\%) possibilities. The form of the listed distributions of the quantitative variables is evaluated with a KolmogorovSmirnov test. Comparative analyzes with a normal distribution of quantitative variables in two independent groups were performed with t-test (independentsamples t-test), and in case the distribution was not normal, the Mann-Whitney test was used. The relationship between the two category variables was examined with a Chi-square test. Statistical significance is assumed at $p$ values less than 0.05 . The specialized Statistical Package for the Social Sciences (SPSS) version 19.0 was used to process the survey data.

\section{Results}

The study of 101 pregnant women with excess body weight and 91 pregnant women with normal body weight revealed differences in the prevalence of high blood pressure, preterm birth, newborn weight, and risk for comorbidities between cases and controls.

Obese women had higher weight $(97.12 \pm 11.11 \mathrm{~kg}), \mathrm{BMI}\left(34.79 \pm 3.71 \mathrm{~kg} / \mathrm{m}^{2}\right)$, and weight of their newborns $(3176.78 \pm 596.51 \mathrm{~g})$ than women with normal weight - respectively, $53.89 \pm 6.31 \mathrm{~kg}$, $20.20 \pm 2.24 \mathrm{~kg} / \mathrm{m}^{2}$, and $2989.98 \pm 630.51 \mathrm{~g}$. Table 1 summarizes the results. No significant difference was found in the age of the mothers in both groups. In our study, the maximum reported birth weight was $5030 \mathrm{~g}$ detected in the case group. Our study found a correlation between maternal obesity and the birth weight of their newborns. We found a significant difference between body weight and BMI in obese patients and the control group $(p<0.001)$.

There was a statistically significant difference in both the systolic and the diastolic blood pressure between the cases and controls(Table 2). Wedetected mean systolic

Table 1: Maternal age, BMI, and weight of the mother and the newborn baby in cases and controls

\begin{tabular}{|c|c|c|c|c|c|c|c|c|c|c|}
\hline & Group & $\mathrm{N}$ & Mean & Median & SD & Min & Max & $\mathrm{t}$ & df & $\mathrm{p}$ \\
\hline \multirow{2}{*}{ Maternal weight } & Controls & 91 & 53,89 & 54,00 & 6,31 & 32,00 & 66,00 & $-32,68$ & 194 & $<0.001$ \\
\hline & Cases & 105 & 97,12 & 95,00 & 11,11 & 80,00 & 160,00 & & & \\
\hline BMI & $\begin{array}{l}\text { Controls } \\
\text { Cases }\end{array}$ & $\begin{array}{l}91 \\
105\end{array}$ & $\begin{array}{l}20,20 \\
3479\end{array}$ & $\begin{array}{l}20,20 \\
34,06\end{array}$ & $\begin{array}{l}2,24 \\
371\end{array}$ & $\begin{array}{l}14,69 \\
29,37\end{array}$ & $\begin{array}{l}24,97 \\
4938\end{array}$ & $-32,57$ & 193 & $<0.001$ \\
\hline Newborn weight & $\begin{array}{l}\text { Controls } \\
\text { Cases }\end{array}$ & $\begin{array}{l}91 \\
105\end{array}$ & $\begin{array}{l}2998,98 \\
3176,78\end{array}$ & $\begin{array}{l}3090,00 \\
3230,00\end{array}$ & $\begin{array}{l}630,51 \\
596,51\end{array}$ & $\begin{array}{l}1180,00 \\
1480,00\end{array}$ & $\begin{array}{l}4330,00 \\
5030,00\end{array}$ & $-2,03$ & 194 & 0.044 \\
\hline Maternal age & $\begin{array}{l}\text { Controls } \\
\text { Cases }\end{array}$ & $\begin{array}{l}91 \\
105\end{array}$ & $\begin{array}{l}29,43 \\
30,20\end{array}$ & $\begin{array}{l}29,00 \\
31,00\end{array}$ & $\begin{array}{l}6,06 \\
6,93\end{array}$ & $\begin{array}{l}15,00 \\
17,00\end{array}$ & $\begin{array}{l}47,00 \\
48,00\end{array}$ & $-0,82$ & 194 & 0.411 \\
\hline
\end{tabular}


Table 2: Comparison between a gestational week at birth, blood pressure, and Apgar score at $1^{\text {st }}$ and $5^{\text {th }}$ min between cases and controls

\begin{tabular}{lllllllll}
\hline Parameter & Group & $\mathrm{N}$ & Mean & Median & SD & Min & Max & p \\
\hline Gestational & Controls & 91 & 37,99 & 38,00 & 2,30 & 31,00 & 42,00 & 0.51 \\
age at birth & Cases & 105 & 37,74 & 38,00 & 2,78 & 21,00 & 42,00 & \\
Systolic blood & Controls & 91 & 113,24 & 110,00 & 11,84 & 90,00 & 150,00 & $<0.001$ \\
pressure & Cases & 105 & 124,93 & 120,00 & 14,61 & 90,00 & 160,00 & \\
Diastolic blood & Controls & 91 & 71,54 & 70,00 & 8,05 & 60,00 & 100,00 & $<0.001$ \\
pressure & Cases & 105 & 78,01 & 80,00 & 8,92 & 60,00 & 95,00 & \\
Apgar score & Controls & 91 & 6,91 & 7,00 & 1,16 & 3,00 & 9,00 & 0.82 \\
at 1 min & Cases & 105 & 6,95 & 7,00 & 0,96 & 3,00 & 9,00 & \\
Apgar score & Controls & 91 & 8,35 & 9,00 & 0,85 & 6,00 & 9,00 & 0.45 \\
at 5 min & Cases & 105 & 8,27 & 8,00 & 0,87 & 6,00 & 9,00 & \\
\hline Analytical test used:Mann-Whitney test. & & & & & &
\end{tabular}

blood pressure in cases to be $124.93 \pm 14.61 \mathrm{~mm} / \mathrm{Hg}$, while in controls, it was $113.24 \pm 11.84 \mathrm{~mm} \mathrm{Hg}$. Mean diastolic blood pressure was $79.01 \pm 8.92 \mathrm{~mm} \mathrm{Hg}$ in cases and $71.54 \pm 8.05 \mathrm{~mm} \mathrm{Hg}$ in controls. Such a difference was not found when comparing gestational age at birth and Apgar score at the $1^{\text {st }}$ and the $5^{\text {th }}$ min.

In the case group, $39 \%(n=41)$ of women were pregnant for the first time, while in the control group $53.8 \%(n=49)$ were pregnant for the first time (Table 3$)$. Consequently, more than one pregnancy was registered in $61 \%(n=56)$ of cases and $46.2 \%(n=42)$ of controls. About $20 \%(n=21)$ of cases had one miscarriage and in the group of controls that percentage was $13.3 \%(n=12)$ (Table 3 ). We found more than one miscarriage in $11.4 \%$ $(n=12)$ of cases and $13.3 \%(n=12)$ of controls. No miscarriage was registered in $73.3 \%(n=66)$ of controls and $68.6 \%(n=72)$ of cases.

Table 3: Parity and miscarriages of cases and controls

\begin{tabular}{|c|c|c|c|c|}
\hline Characteristics & & Controls & Cases & All \\
\hline \multicolumn{5}{|l|}{ Parity } \\
\hline \multirow[t]{2}{*}{ First pregnancy } & $\mathrm{n}$ & 49 & 41 & 90 \\
\hline & $\%$ & 53.8 & 39.0 & 45.9 \\
\hline \multirow[t]{2}{*}{ Second pregnancy } & $\mathrm{n}$ & 27 & 36 & 63 \\
\hline & $\%$ & 29.7 & 34.3 & 32.1 \\
\hline \multirow[t]{2}{*}{ Third pregnancy } & $n$ & 8 & 20 & 28 \\
\hline & $\%$ & 8.8 & 19.0 & 14.3 \\
\hline \multirow[t]{2}{*}{ Forth pregnancy } & $\mathrm{n}$ & 5 & 6 & 11 \\
\hline & $\%$ & 5.5 & 5.7 & 5.6 \\
\hline \multirow[t]{2}{*}{ Fifth pregnancy } & $\mathrm{n}$ & 2 & 1 & 3 \\
\hline & $\%$ & 2.2 & 1.0 & 1.5 \\
\hline \multirow[t]{2}{*}{ Sixth pregnancy } & $\mathrm{n}$ & 0 & 1 & 1 \\
\hline & $\%$ & 0.0 & 1.0 & 0.5 \\
\hline \multicolumn{5}{|c|}{ Number of miscarriages } \\
\hline \multirow[t]{2}{*}{0} & $\mathrm{n}$ & 66 & 72 & 138 \\
\hline & $\%$ & 73.3 & 68.6 & 70.8 \\
\hline \multirow[t]{2}{*}{1} & $\mathrm{n}$ & 12 & 21 & 33 \\
\hline & $\%$ & 13.3 & 20.0 & 16.9 \\
\hline \multirow[t]{2}{*}{2} & $n$ & 11 & 12 & 23 \\
\hline & $\%$ & 12.2 & 11.4 & 11.8 \\
\hline \multirow[t]{2}{*}{3} & $\mathrm{n}$ & 1 & 0 & 1 \\
\hline & $\%$ & 1.1 & 0.0 & 0.5 \\
\hline
\end{tabular}

We found a significant difference in the preterm birth between cases and controls (Table 4). Preterm delivery was defined as a birth occurring before the

Table 4: Time of birth depending on the gestational age

\begin{tabular}{llllll}
\hline Time of birth & & Controls & Cases & Total & $\mathrm{p}$ \\
\hline Preterm birth & $\mathrm{n}$ & 16 & 26 & 42 & 0.018 \\
& $\%$ & 17.6 & 24.8 & 21.4 & \\
On term & $\mathrm{n}$ & 65 & 55 & 120 & \\
& $\%$ & 71.4 & 52.4 & 61.2 & \\
Post-term birth & $\mathrm{n}$ & 10 & 24 & 34 & \\
\multirow{2}{*}{ Total } & $\%$ & 11.0 & 22.9 & 17.3 & \\
& $\mathrm{n}$ & 91 & 105 & 196 & \\
& $\%$ & 100.0 & 100.0 & 100.0 &
\end{tabular}

27 g.w. About $24.8 \%(n=26)$ of cases gave birth before term and $52.4 \%(n=55)$ on-term. In the control group, the results show $17.6 \%(n=16)$ preterm births and $71.4 \%(n=65)$ on-term births.

We confirmed a significant difference when comparing comorbidities in cases and controls (Table 5). Comorbidities were detected in $43.8 \%(n=46)$ of cases and in $25.2 \%(n=22)$ of controls. High blood pressure was registered in $26.7 \%(n=28)$ of our cases. We have assumed values for high blood pressure to be systolic blood pressure $\geq 140 \mathrm{~mm} \mathrm{Hg}$ and diastolic blood pressure $\geq 90 \mathrm{~mm} \mathrm{Hg}$. We measured it in two separate occasions after the 20 weeks of gestation and with the exclusion of proteinuria. Studies show that high blood pressure, especially in obese patients is a high-risk factor for preterm birth.

Table 5: Comorbidities of pregnant women

\begin{tabular}{llllll}
\hline Disease during pregnancy & & Controls & Cases & Total & $\mathrm{p}$ \\
\hline None & $\mathrm{n}$ & 69 & 59 & 128 & $<0.001$ \\
& $\%$ & 75.8 & 56.2 & 65.3 & \\
High blood pressure & $\mathrm{n}$ & 2 & 28 & 30 & \\
Thyroiditis & $\%$ & 2.2 & 26.7 & 15.3 & \\
Gastritis & $\mathrm{n}$ & 4 & 5 & 9 & \\
& $\%$ & 4.4 & 4.8 & 4.6 & \\
Varices & $\mathrm{n}$ & 2 & 3 & 5 & \\
& $\%$ & 2.2 & 2.9 & 2.6 & \\
Others & $\mathrm{n}$ & 1 & 2 & 3 & \\
& $\%$ & 1.1 & 1.9 & 1.5 & \\
Diabetes & $\mathrm{n}$ & 7 & 8 & 15 & \\
\multirow{2}{*}{ Total } & $\%$ & 7.7 & 7.6 & 7.7 & \\
& $\mathrm{n}$ & 6 & 0 & 6 & \\
& $\%$ & 6.6 & 0.0 & 3.1 & \\
\hline
\end{tabular}

The most common thyroid pathology in pregnancy is Hashimoto thyroiditis. It was registered in $4.8 \%(n=5)$ of cases and $2.2 \%(n=4)$ of controls. Hypothyroidism during pregnancy has been associated with a higher incidence of miscarriage, intrauterine growth retardation, preterm delivery, and cognitive impairment in the offspring [8].

Gestational diabetes mellitus (GDM) is defined as any glucose intolerance with the onset or first recognition during pregnancy. We used a $50 \mathrm{~g}$ (OGCT) as a screening method for GDM at 24-28 weeks of gestation. It was registered in none of the cases and $6.6 \%(n=6)$ of controls.

\section{Discussion}

Our study investigates the correlation between overweight in pregnant women and some complications concerning maternal and neonatal health. We examined the preterm delivery as one of the most serious consequences of mothers with $B M I \geq 25 \mathrm{~kg} / \mathrm{m}^{2}$. We found that excessive body weight is a risk factor for preterm delivery [9]. Furthermore, we investigated some chronic diseases with higher frequency in obese women than in women with normal weight. Some of 
these diseases are independent risk factors for preterm delivery. Our statistical analysis confirmed significantly higher systolic and diastolic blood pressure in cases compared to controls. We found association neither between maternal BMI and the age of delivery nor between the maternal BMI and Apgar score at $1^{\text {st }}$ and $5^{\text {th }} \mathrm{min}$. These findings emphasize the need for accurate monitoring of women with BMl above normal as they may be considered high-risk pregnancies.

Obesity during pregnancy is a disease that affects both the mother and the fetus. Many authors report a wide range of effects on the fetus, the newborn, and the child [10], [11], [12]. Short-term effects affect the prenatal and neonatal periods. Obesity increases the risk of fetal malformations, spontaneous, extremely preterm delivery, and stillbirth [10]. Comorbidities such as preeclampsia, gestational hypertension also affect fetal development and growth. Obese patients are at increased risk of primary Cesarean section. The higher the frequency of Cesarean section may affect the newborn due to the increased risk of respiratory disease, neonatal intensive care units (NICU) admissions, and longer length of hospital stay [13]. Josefson et al. established that obese women transfer less vitamin $D$ to offspring compared to normal-weight women [12]. Increased adipose tissue reduces serum levels of vitamin $D$ due to its sequestration into adipose tissue. This leads to less accumulation of vitamin $D$ in the fetus.

We can say with a high degree of certainty that maternal obesity is associated with increased birth weight and increased neonatal adiposity [12]. A metaanalysis including 21 studies summarizes that maternal obesity increases the risk of fetal macrosomia [11] Macrosomia is defined as birth weight greater than $4500 \mathrm{~g}$, regardless of gestational age. In our study, the maximum reported birth weight was $5030 \mathrm{~g}$. Our study found a significant correlation between maternal obesity and the birth weight of their newborns $(p=0,044)$. Other authors also report a similar relationship between these parameters [12], [13]. We found a significant difference between body weight and BMI in obese patients and the control group $(p<0,001)$. Moreover, no significant difference was found in the number of births and miscarriages. Of course, many more studies need to be done to help us understand these processes better.

Newborns of obese mothers have been found to have higher levels of leptin and interleukin 6 (IL-6) in the umbilical cord and higher insulin resistance [14]. Those are some of the long-term consequences of maternal obesity. Long-term metabolic effects may affect the health and well-being of the offspring. Increased birth weight is associated with an increased risk of obesity in childhood [14]. In addition to higher weight and BMI, higher systolic pressure was found in early childhood. Cesarean delivery increases the risk of chronic childhood illness - asthma, allergies, obesity, diabetes mellitus, and impaired intestinal microbiome [15], [16].
During the time of our investigation, we notice that young women do not pay enough attention and are not well informed about the risks overweight may bring. Our society is used to people with increasing weight and $\mathrm{BMI}$ and even tries to tolerate them. We think than preserving health is the most important value and we must try our best to educate people in this direction and find new methods to predict complications [17]. Women should understand the impact of their overweight over their birth potential. Help should be offered to all of them to decrease the possible risks.

\section{Conclusion}

Maternal overweight and obesity and underlying high blood pressure are risk factors for preterm delivery. Pregnancy is metabolic distress for all women, but those with obesity and high blood pressure have less potential to adapt to the changes. As a consequence, these women are at increased risk for other disorders and delivery before term. Therefore, obstetricians should advise their patients to make an effort for weight reduction, preferably before birth to prevent complications during pregnancy.

\section{Acknowledgments}

We owe special thanks to Mr. T. Kundurdgiev for the statistical support.

\section{References}

1. Vernini JM, Moreli JB, Magalhães CG, Costa RA, Rudge MV Calderon IM. Maternal and fetal outcomes in pregnancies complicated by overweight and obesity. Reprod Health. 2016;13(1):100. https://doi.org/10.1186/s12978-016-0206-0 PMid:27567898

2. Karamisheva V, Ivanov S, Nachev A, Marinov B, Jordanova D, Basheva S. Preterm birth--incidence and etiology. Akush Ginekol (Sofiia). 2013;52 Suppl 2:11-4

PMid:24294755

3. Hitrova-Nikolova S, Nikolov A, Vakrilova L, Yarakova N, Pramatarova T, Popivanova A, et al. Socio-demographic characteristics and Vitamin D status in women born before 32 weeks'. Akush Ginekol (Sofiia). 2014;53(5):27-34. PMid:25558668

4. Slack E, Best KE, Rankin J, Heslehurst N. Maternal obesity classes, preterm and post-term birth: A retrospective analysis of 479,864 births in England. BMC Pregnancy Childbirth. 2019;19(1):434. https://doi.org/10.1186/s12884-019-2585-z PMid:31752763 
5. Cnattingius S, Villamor E, Johansson S, Edstedt Bonamy AK, Persson M, Wikstrom AK, et al. Maternal obesity and risk of preterm delivery. JAMA. 2013;309(22):2362-70. https://doi. org/10.1001/jama.2013.6295

\section{PMid:23757084}

6. Johansson S, Villamor E, Altman M, Bonamy AK, Granath F, Cnattingius S. Maternal overweight and obesity in early pregnancy and risk of infant mortality: A population based cohort study in Sweden. BMJ. 2014;349:g6572. https://doi. org/10.1136/bmj.g6572

7. Liu P, Xu L, Wang Y, Zhang Y, Du Y, Sun Y, et al. Association between perinatal outcomes and maternal pre-pregnancy body mass index. Obes Rev. 2016;17(11):1091-102. https://doi. org/10.1111/obr.12455

PMid:27536879

8. Karamisheva V, Ivanov S, Nikolov A, Jordanova D, Dimitrov G, Nachev A. Perinatal mortality of IUGR neonates. Akush Ginekol (Sofiia). 2014;53 Suppl 1:13-5. PMid:25510035

9. Marinov B, Andreeva A, Karamisheva V, Museva A. Preterm birth in Bulgaria--changes in aetiology and incidence in the last decade. Akush Ginekol (Sofiia). 2014;53 Suppl 1:33-9. PMid:25510040

10. Mariona FG. Perspectives in obesity and pregnancy. Womens Health (Lond). 2016;12(6):523-32.

PMid:29334009

11. Stubert J, Reister F, Hartmann S, Janni W. The risks associated with obesity in pregnancy. DtschArztebl Int. 2018;115(16):276-83. https://doi.org/10.3238/arztebl.2018.0276

PMid:29739495

12. Josefson JL, Feinglass J, Rademaker AW, Metzger BE, Zeiss DM, Price HE, et al. Maternal obesity and Vitamin D sufficiency are associated with cord blood Vitamin D insufficiency. J Clin Endocrinol Metab. 2013;98(1):114-9. https:// doi.org/10.1210/jc.2012-2882

PMid:23144468

13. Papachatzi E, Paparrodopoulos S, Papadopoulos V, Dimitriou G, Vantarakis A. Pre-pregnancy maternal obesity in Greece: A case-control analysis. Early Hum Dev. 2016;93:5761. https://doi.org/10.1016/j.earlhumdev.2015.12.006 PMid:26802788

14. Howell KR, Powell TL. Effects of maternal obesity on placental function and fetal development. Reproduction. 2017;153(3):R97108. https://doi.org/10.1530/rep-16-0495

PMid:27864335

15. Yankova Y, Nikolov A, Nashar S, Vakrilova L. CRIB II score and method of delivery for very low and extremely low birth weight infants. Akush Ginekol (Sofiia). 2012;51(3):3-8. PMid:23236658

16. Hitrova-Nikolova S, Karamisheva V, Slancheva B. The newborn infant by caesarean section. Akush Ginekol (Sofiia). 2020;59(1):32-7.

17. Karamisheva V, Ivanov S, Nikolov A, Jordanova D, Dimitrov G, Nachev A. Identification the risk of preterm labor: The role of fetal fibronectin. Akush Ginekol (Sofiia). 2015;54(1):3-6.

PMid:25909122 